\title{
Nurturing regional innovation: the effects of bank competition in U.S
}

Article

Accepted Version

Tian, L. and Han, L. (2021) Nurturing regional innovation: the effects of bank competition in U.S. International Journal of Banking, Accounting and Finance, 12 (1). pp. 75-96. ISSN 1755-3830 doi: https://doi.org/10.1504/IJBAAF.2021.111805 Available at https://centaur.reading.ac.uk/85780/

It is advisable to refer to the publisher's version if you intend to cite from the work. See Guidance on citing.

To link to this article DOI: http://dx.doi.org/10.1504/IJBAAF.2021.111805

Publisher: Inderscience

All outputs in CentAUR are protected by Intellectual Property Rights law, including copyright law. Copyright and IPR is retained by the creators or other copyright holders. Terms and conditions for use of this material are defined in the End User Agreement.

\section{www.reading.ac.uk/centaur}

\section{CentAUR}

Central Archive at the University of Reading

Reading's research outputs online 


\title{
Nurturing regional innovation: the effects of bank competition in U.S
}

\author{
Lin Tian ${ }^{1}$ and Liang $\operatorname{Han}^{2, *}$ \\ ${ }^{1}$ School of Management and Economics, University of Electronic Science and Technology of China, \\ Chengdu, 610054, China. Lin.Tian@uestc.edu.cn \\ ${ }^{2}$ School of Accounting, Tianjin University of Finance and Economics, Tianjin, 300222, China; Henley \\ Business School, University of Reading, Reading, RG6 6UD, U.K. Liang.Han@ henley.ac.uk \\ * Corresponding author
}

\begin{abstract}
Authors bio:
Dr Lin Tian earned a PhD from Surrey University and is a Postdoctoral Fellow at School of Management and Economics, University of Electronic Science and Technology of China. Dr Tian's research focuses on banking market structure, corporate innovation and corporate finance. Dr Tian has published in Review of Quantitative Finance and Accounting, China Economics Review and other major journals in economics and finance.
\end{abstract}

Professor Liang Han obtained his PhD from Warwick Business School and is a Professor in Accounting and Finance at both School of Accounting, Tianjin University of Finance and Economics, China and Henley Business School, University of Reading, U.K. Prof Han has published in Journal of Banking \& Finance, Journal of Business Finance and Accounting with research interests in banking market structure, corporate finance and small business finance. Prof Han serves as a consulting editor for International Small Business Journal.

\begin{abstract}
Whilst corporate innovation is one of the key drivers of regional economic growth, question remains over how regional corporate activities are affected by local banking market structure. By attaching regional corporate innovation activities to a market power hypothesis, this paper examines (1) if regional innovation activities would benefit from the improved banking market competition and (2) the variation of banking market competition effects on innovation outputs over unique regional characteristics, such as state-level R\&D intensity and distribution of innovation activities. Using patent and citation data and local bank data from 51 states in U.S between 1992 and 2004, we show that improved local banking market competition increases both the quantity (patents) and quality (citations) of regional innovation outputs. It is also found that such a favourable effect on regional innovation is especially stronger for those states with low R\&D intensity and those with more concentrated innovation activities.
\end{abstract}

\section{Keywords}

Regional innovation; Banking market; R\&D intensity; 


\section{Introduction}

Innovation has been widely accepted as a driving force for corporate long-term success and economic growth and empirical studies on financing innovation have mainly focused on the role played by government support (e.g. Hong et al., 2016; Uyarra et al., 2017) and equity investors (e.g. Wonglimpiyarat, 2013). Since banking market deregulation in U.S in 1990s, recent empirical studies have attempted, over the last decade, to investigate how corporate innovation activities would be affected by banking market structure, in terms of deregulations (Amore et al., 2013; Chava et al., 2013; Cornaggia et al., 2015; Hombert and Matray, 2017) and market development (Benfratello et al., 2008; Hsu et al., 2014). This is important because corporate innovation activities carry a nature of high uncertainty and information opaqueness and banks have been identified as an important financial intermediary to finance risky and informationally opaque projects (e.g. Berger et al., 2005). Meanwhile, both theoretical and empirical ambiguities persist where banking market competition may improve credit supply to finance innovation but harm banks' motivation to invest in private information collection from informationally opaque innovation projects. For example, the favourable effects of banking market deregulation have been found to be driven by the greater capabilities gained by banks to diversify risk and to supply credit after deregulation (e.g. Amore et al., 2013). Deregulation, however, may have an adverse impact on corporate innovation activities carried out by public firms where banking competition reduces the supply of innovative targets - those small and innovative enterprises which have a greater dependence on external bank credit to finance their innovation activities (Cornaggia et al., 2015).

The number of patents in U.S has increased significantly over the last few decades. Figure 1 shows that, between 1992 and 2004, the number of patents granted, excluding those to universities, foreign companies and governments, had doubled and the contribution made by private firms increased over time. Such a pattern is in line with the pace of banking market 
deregulation at state level in U.S in the same period (Rice and Strahan, 2010). Indeed, innovation has been recognized as one of the key drivers of regional economic growth (Capello and Lenzi, 2014) and a well-functioning financial system is expected to facilitate innovation activities (Berger et al., 2005). However, what is less understood is about how regional innovation are affected by local banking market structure and this paper is aimed to fill in this research gap. This is fundamentally important because an investigation at regional (e.g. state) level enables us to capture the aggregate effects of local banking market structure on regional innovation outputs. Because of the variation of banking market competition effects on innovation over firm level characteristics, corporate innovation could be more active in those states with a driving force from small innovative firms; while in a state dominated by large innovative public firms, innovation could become less active (Cornaggia et al., 2015). A regional study at state level may also help policy-makers set up more 'tailored' policies to facilitate regional corporate innovation activities (Hsu et al., 2014).

Figure 1: Number of Patents Granted in U.S. (1992-2004)

Source: National Bureau of Economics Research (NBER) patent database and recalculated by authors.

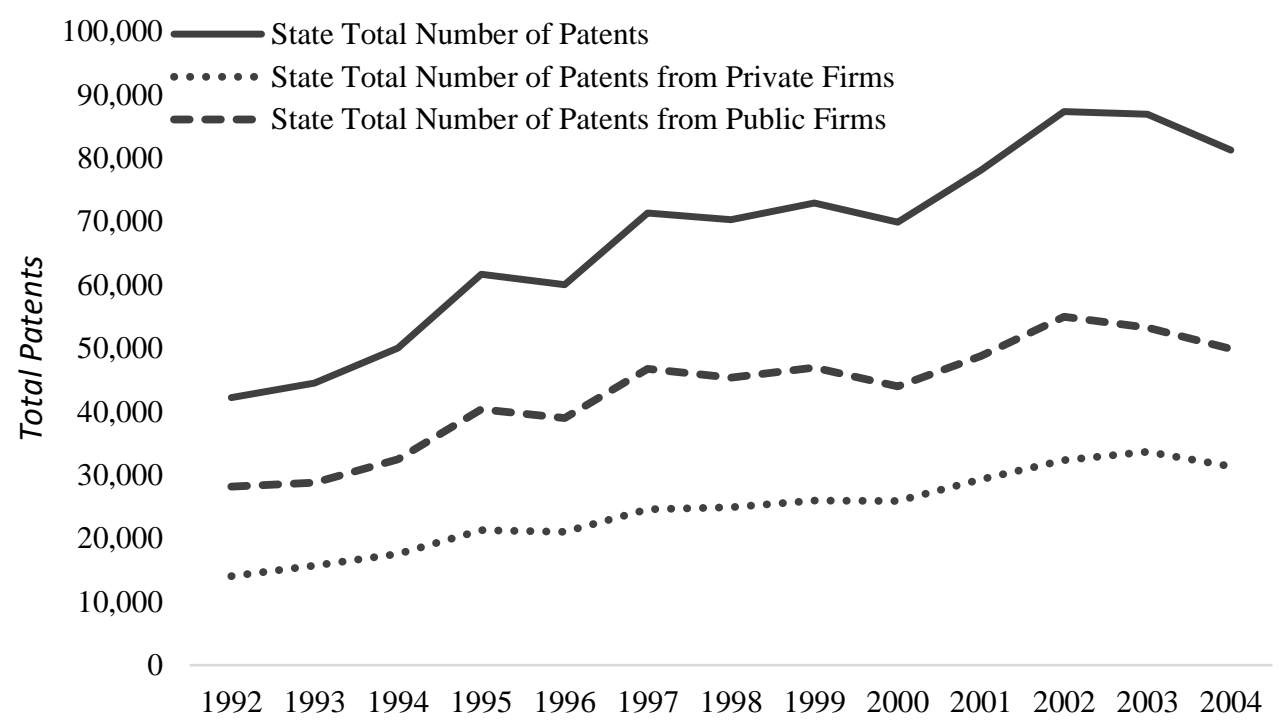


Using panel data of 51 states in U.S. between 1992 and 2004 and patent-metrics as a measure of innovation, we show that, at state level in U.S, regional corporate innovation outputs benefit from improved local banking market competition. For example, a 0.1 increase in $\mathrm{H}$-statistic, a banking competition measure ranging from 0.114 to 1 (mean $=0.644 ; \delta=$ 0.248), would increase both the quantity (patents) and quality (citations) of innovative outputs by about $11 \%$ and $1 \%$ respectively, equivalent to additional 140 patents and 107 citations annually for every USD $\$ 100$ million GDP in each state in U.S. Contributing to existing literature on innovation, we also investigate the mitigating effects of regional innovation patterns, which have been under studied in recent firm level research on innovation. Firstly, we show that with improved banking market competition, states with low R\&D intensity would generate more additional innovation outputs than those states with high $R \& D$ intensity. This is because innovation would make a greater marginal economic contribution in those states with low R\&D intensity. Secondly, we find that innovation activities (e.g. patent numbers) in those states with more concentrated patent types would benefit more from the improved banking market competition.

Section 2 develops theoretical frameworks and hypotheses and Section 3 discusses the data and empirical strategies. We present the empirical results in the following two sections and finally, we conclude and provide implications.

\section{Theoretical framework and hypothesis development}

Because of ex ante financing structure and economic performance, firms may face financial constraints which reduce their likelihood of carrying out innovation activities (Savignac, 2008). Financing behaviour also varies over R\&D intensity of innovative firms. For example, innovative firms are more likely to raise funds by issuing equity and this propensity increases with their R\&D intensity (Casson et al., 2008), suggesting a well-functioning equity market 
encourages innovation investments and in such markets, "it is possible for innovative firms to raise desirable levels of cash for R\&D projects" (p.217). A well-functioning banking market would be especially important for smaller firms who have limited internal resources and restricted access to equity markets to carry out innovation activities (Czarnitzki and Hottenrott, 2011).

According to the information hypothesis, credit supply to the informationally opaque borrowers and projects, such as innovation activities, would be greater in a concentrated market. This is because market power enables banks to extract informational rent (Stiglitz, 2002) and banks with greater market power would have stronger incentives to invest in private information collection (Petersen and Rajan, 1995). In contrast, the market power hypothesis suggests that regional innovation would benefit from banking market competition due to the improved credit supply (Boot and Thakor, 2000), lowered credit prices (Black and Strahan, 2002) and improved bank operating efficiency (Benfratello et al., 2008). Therefore, monopoly power in local banking would drive higher interest rates which have an adverse impact on the growth of technological innovation and productivity. Supporting evidence on market power hypothesis has shown that banking development in the aftermath of deregulation may generate an outward shift in the supply of credit and a decrease in the mark-up in the banking sector, leading to a greater supply of funds and lower rates for all investment projects, including those high risky innovations (e.g. Benfratello et al., 2008; Amore et al., 2013; Hsu et al., 2014). While recent studies have examined the impacts of banking deregulations and market development on corporate innovation activities and the variation of such effects at firm level, the evidence at regional level is rare. Based on the market power hypothesis and the favourable effects of banking market deregulation on firm level innovation, we hypothesize:

H1: Improved local banking market competition increases regional innovation outputs. 
Prior literature has shown that many regional factors have significant impacts on corporate innovation activities, such as commercialization strategies (Breznitz et al., 2008), socioeconomic characteristics (Redmond, 1994), specialization capabilities (Morgan, 2016); market intelligence (Mishra et al., 1996), and knowledge infrastructure (Melançon and Doloreux, 2013). Therefore, the above hypothesized favourable effects of banking market competition on regional innovation activities could also vary over regional characteristics, such as R\&D intensity at state level. Due to the cost and limited availability of credit supply in a concentrated banking market (market power hypothesis), it is expected that with additional credit supply caused by increased bank competition, the marginal economic contribution of innovation would be greater in those 'less innovative' regions than in those 'more innovative' regions. Therefore, we hypothesize that

H2: The favourable effects of local banking market competition on regional corporate innovation would be stronger in regions with low innovation intensity than in regions with high innovation intensity.

Asymmetric information has been identified as a problem a lender has to face when financing innovation activities. Francis et al. (2012) find that patenting and citations could work as a well-functioning signal to alleviate such asymmetric information problem and borrowers with higher innovation capabilities would enjoy lower bank-loan spreads and better non-pricerelated loan terms. Banking market competition could also have a more significant effect on the concentrated patenting activities. This is because innovation is information-sensitive and it is the embodiment and synthesis of collective knowledge and experiences (Pavitt, 2001). From both evolutionary and resource-based perspectives, the dynamic nature of innovation implies that firms with unique innovative capabilities would innovate in particular areas of 
technological frontier more efficiently than others (Dosi, 1982), resulting in an increase of information rents over time. Hence, it is expected that more concentrated innovation activities are characterized by a higher degree of proprietary information specialization.

From bank's perspective, it is risky to finance innovation activities because of the uncertainty associated with innovation outcomes (Amit et al., 1990) and the problem of asymmetric information (Hall et al., 2005). Banks could channel funds either to more concentrated types of innovation activities (e.g. focusing on biomedical products only) for the reason of economies of scale in terms of collecting more specialized information or to more dispersed innovation activities to diversify risk with a greater variety of information to be collected. Instead of the traditional arguments on relationship lending (information hypothesis), current literature has proposed that greater competition in local banking market would improve bank cost efficiency (Chortareas et al., 2016) and lead banks to increase credit supply to small, proximate and opaque borrowers (Tian and Han, 2018). As a result, banks would create a competitive edge that helps insulate themselves from pure price competition from outside banks (Boot and Thakor, 2000). Based on the asymmetric information argument, we therefore hypothesize that

H3: Regions with more specialized innovation activities would benefit more from increased local banking market competition. 


\section{Data and Empirical Strategy}

\subsection{Data}

Innovation is measured within a patent metrics from National Bureau of Economics Research (NBER) patent database (1976-2004) which contains information on the patents granted by the United States Patent and Trademark Office (USPTO), 97\% of which are product patents (Chava et al., 2013). Sample patents granted to universities, governments and foreign companies are excluded because they have weak dependence on local banking markets. Banking market structure is measured at a state level, which is based on the values disclosed at the end of a fiscal year by banks operating in each state in U.S and collected from Federal Deposit Insurance Corporation (FDIC). The sample excludes 'irregular' banks such as investment banks, media and long term credit banks, mortgage banks, and specialised governmental credit institutions. This is because they do not provide credit in return to interest income to the private firms for investment, or they are banks whose primary objectives are not for profit maximisation. Relevant information for control variables used in the analysis is collected from Federal Reserve Bank of St. Louis and U.S. National Science Board (NSB). In total, the analysis makes use of 663 state-year observations for 51 states (including the District of Columbia) in U.S. between 1992 and 2004.

\subsection{Measuring Regional Innovation}

A patent-metrics has been widely used in evaluating innovation performance and it has been acknowledged that the numbers of patents (quantity) and citations of patents (quality) are more appropriate $^{1}$ proxies for innovation than others, such as R\&D expenditure (Chava et al., 2013), to capture technological advances and to represent the output and commercialization of innovation activities. The level of regional innovation activities is captured by the total number 
of patents $\left(\right.$ Patent $\left._{i t}\right)$ and citations $\left(\right.$ Citation $\left._{i t}\right)$ that are filed to all relevant businesses headquartered in state $i$ in year $t$. Further, to control for the timing issue between patenting and innovation investments and for the size effects, regional Patent and Citation in year $t$ are adjusted by taking the average within three years (year $t$ to $t+2$ ) and using natural log transformed and state GDP standardized measures, $\ln ($ Patent $/ G D P)$ and $\ln ($ Citation $/ G D P)$.

\subsection{Measuring Local Banking Market Competition}

Local banking market competition is measured by RSIndex (Rice and Strahan, 2010) and Panzar-Rosse H-statistic (Panzar and Rosse, 1984). RSIndex is a categorical index evaluating the openness of a state to interstate branching, ranging from 0 (deregulated) to 4 (highly regulated). The measure is based on the staggered deregulation of interstate bank branching acts (i.e. Riegle-Neal Interstate Banking and Branching Efficiency Act, IBBEA) implemented in the United States in 1990s. Rice and Strahan (2010) show that firms, in states more open to branching, enjoy lower interest rates and thus result in an increased use of bank debt. Following ample empirical literature that has examined various consequences of deregulations, banking market development in the aftermath of deregulation is expected to generate an outward shift in the supply of credit and a decrease in mark-up in the banking sector for all investment projects, including those risky innovations (Cornaggia et al., 2015).

The key weakness of using deregulation, however, lies in the nature of such measures. The categorical RSIndex, for example, is usually monotonic and fails to fully capture the trivial changes of regional banking market competition. It also ignores the long term equilibrium of local market and has other weaknesses. For example, individual states implemented the interstate deregulation to various extents and at different times (Strahan, 2003), while the index is not observable before the effective date of state openness to interstate branching. The deregulation also involves various factors which may have no apparent relation to the changes 
of local market competition. To address the issue, this paper also uses Panzar-Rosse H-statistic ${ }^{2}$ ( $H$ henceforth) with a long term equilibrium to measure banking market competition. $H$ is robust and superior to other measures in evaluating the degree of competition because it is derived from profit-maximizing equilibrium conditions (Claessens and Laeven, 2004) and it has been widely used to test banking market competition (Bikker and Haff, 2002). Empirically, a reduced-form revenue equation is specified to measure $H$ as below:

$$
l=\beta_{0}+\beta_{1} l+\beta_{2} l+\beta_{3} l+\sum_{n=1}^{m} \gamma_{n} Z_{n, j t}+\varepsilon_{j t}
$$

where $T R_{j t}$ denotes bank $j$ 's output price in year $t$, measured as the ratio of total revenue to total assets to account for bank size differences. $w_{1, i t}$ is the input price of labour (personnel expenses/number of employees), $w_{2, i t}$ is the input price of deposit (interest expenses/total deposits and money market funding), and $w_{3, i t}$ is the input price of capital (other operating and administrative expenses/total assets). $Z_{n, j t}$ is a vector of additional explanatory variables, reflecting differences in costs, size, risk, structure and product mix. $H$ then is measured by $H=$ $\beta_{1}+\beta_{2}+\beta_{3}$. For robustness, alternative competition or concentration measures are used, such as state level branch density and Herfindahl-Hirschman Index (HHI).

\subsection{Control Variables}

The following analysis also controls for traditional regional determinants, such as the quality of human, social capital and public infrastructures (Furman et al., 2002; Cornaggia et al., 2015). In specific, labour force concentration (employment/population), unemployment rate, science and engineering degrees as a percentage of higher education degrees conferred, and federal R\&D obligations per employee at state level are considered. All variables used in the following empirical analysis are defined in detail in Appendix. 


\subsection{Empirical Methods}

The baseline model to evaluate the effects of banking market competition on regional innovation is as follows:

$$
\ln \left(\text { Innovation }_{i t}\right)=\alpha_{1}+\beta_{1} \text { Competition }_{i t}+\gamma_{1 k} \sum X_{k, i t}+Y E A R_{t}+\varepsilon_{1 i t}
$$

where regional Innovation $_{i t}$ is measured by state size-standardized patents (Patent/GDP) and citations (Citation/GDP). Competition $i t$ is state $i$ 's banking market competition in year $t$. $X_{i t}$ refers to a vector of state specific control variables. Year fixed effects, $Y E A R_{t}$, are used to control for time-specific trend.

Regional banking market competition shows a pattern of long term equilibrium and is potentially endogenous. The endogeneity ${ }^{3}$ of H-statistic $\left(H_{i t}\right)$ in the analysis is controlled by an instrument of state median Tier 1 risk-based ratio (Tier 1 ratio $_{i t}$ ) as follows, relying on the fundamental nature of competitive markets where new players and those that fail enter and exit the market freely (Tian and Han, 2018).

$$
H_{i t}=\alpha_{2}+\beta_{2} \text { Tier } 1 \text { ratio }_{i t}+\gamma_{2 k} \sum X_{k, i t}+Y E A R_{t}+\varepsilon_{2 i t}
$$

The second-stage equation then estimates the impact of $H$ on regional innovation outputs:

$$
\ln \left(\text { Innovation }_{i t}\right)=\alpha_{3}+\beta_{3} \widehat{H_{l t}}+\gamma_{3 k} \sum X_{k, i t}+Y E A R_{t}+\varepsilon_{3 i t}
$$

where $\widehat{H_{l t}}$ is the predicted value from Eq. (3). With a valid instrumental variable, $\beta_{3}$ would capture the determinant effects of local banking market competition on regional corporate innovation outputs without bias. The instrumental variable estimator is implemented by using a two-stage least squares (2SLS) approach. 


\section{Empirical results}

\subsection{Descriptive Statistics}

Table 1 reports the descriptive statistics of the variables used in the following empirical analysis and shows that averagely, each state obtains 980 patents per year and they attract around 13,000 citations. RSIndex has an average of 2.24 which is lower than that (3.5) from Cornaggia et al. (2015) whose data are between 1975 and 2005, suggesting an increased competition in banking market at state level. $H$ takes into account the long term equilibrium in banking markets at state level and ranges from 0.114 to 1 with an average of 0.644 (monopolistic competition) and a standard deviation of 0.248 .

\begin{tabular}{lccccc}
\hline Table 1 Descriptive Statistic & \multicolumn{5}{c}{} \\
\hline Variables & Obs & Mean & Std. dev. & Min & Max \\
\hline Innovation variables & & & & & \\
\hline Patent & 663 & 980 & 2,005 & 0 & 17,106 \\
Citation & 663 & 12,986 & 27,165 & 0 & 262,295 \\
Innovator & 645 & 610 & 1273.792 & 1 & 9,345 \\
Patent $R \& D(\$ M)$ & 663 & 0.228 & 0.499 & 0 & 6.719 \\
Citation/Patent & 645 & 107.583 & 914.769 & 4.243 & 15,512 \\
\hline Banking market competition variables & & & & & \\
\hline RSIndex & 561 & 2.242 & 1.429 & 0 & 4 \\
H-statistic & 663 & 0.644 & 0.248 & 0.114 & 1.000 \\
HHI & 561 & 0.108 & 0.079 & 0.012 & 0.551 \\
Branch density & 663 & 0.602 & 0.401 & 0.004 & 3.315 \\
Control variables & & & & & \\
Labour force concentration & 663 & 64.049 & 4.365 & 34.400 & 73.300 \\
Unemployment rate & 663 & 5.139 & 1.419 & 2.300 & 11.200 \\
Income* & 663 & $26,574.510$ & $5,929.716$ & $14,812.100$ & $52,009.000$ \\
Science and engineering degrees $(\%)$ & 663 & 29.949 & 4.556 & 19.300 & 45.100 \\
Federal R\&D obligations* & 663 & 690.074 & $1,376.632$ & 42.000 & $11,544.000$ \\
Venture capital & 663 & 0.003 & 0.016 & 0.000 & 0.301 \\
\hline Nore: This
\end{tabular}

Note: This table reports the descriptive statistics of the variables used in the empirical analysis, including those used in robustness and additional tests. The samples collected are from 1992 to 2004 in 51 states (include District of Columbia). Variables with * are measured in natural logarithm in the estimations. The detailed description of all variables are provided in Appendix. The descriptive statistics of the variables used in the estimation of $\mathrm{H}$-statistics are not reported but available from the authors on request. 


\subsection{Regional Innovation Outputs and Banking Market Competition: Baseline Results}

Table 2 reports the baseline results where OLS models (Models 1, 2, 5 and 6) follow existing literature and take branching deregulation, RSIndex, as an exogenous measure of banking market competition. It shows that aggregate state level innovation outputs increase with less interstate branching restriction (measured by lower RSIndex). Specifically, each state, on average, would increase their patent and citation numbers annually by $10.71 \%$ and $1.20 \%$ respectively when RSIndex decreases by one unit, suggesting a favourable effect of the geographical relaxation of banking market restrictions on state-level innovation.

2SLS models (Models 3, 4, 7 and 8), instead, control for the endogeneity ${ }^{4}$ by an instrumented $H$ as an alternative measure of banking market competition and the results of Eq. (4) show consistent evidence on the favourable effect of banking market competition on regional innovation. On average, each state would generate around 104 additional patents (Model 4) and 107 additional citations (Model 8) for every US\$100 million GDP annually, with an increase of $H$ by 0.1 . This is equivalent to a $10.61 \%$ increase in patent counts and a $0.82 \%$ increase in citations. The results of other control variables are also fundamentally consistent with the expectations that higher quality of employees and better social capital and public infrastructures at state level would have a positive impact on regional innovation outputs. The baseline results are in favour of existing literature on the availability of external finance (e.g. Rice and Strahan, 2010) and support the market power hypothesis that innovative firms would have a better and cheaper access to external finance in a region with more competitive banking market. Overall, our results support H1. 
Table 2 Corporate Innovation and Banking Market Competition at State-Year Level: Baseline Analysis

\begin{tabular}{|c|c|c|c|c|c|c|c|c|}
\hline & \multicolumn{4}{|c|}{ ln $(\text { Patent } / G D P)_{i t}$} & \multicolumn{4}{|c|}{$\ln (\text { Citation/GDP })_{i t}$} \\
\hline & $\begin{array}{c}\text { OLS } \\
(1)\end{array}$ & $\begin{array}{c}\text { OLS } \\
(2)\end{array}$ & $\begin{array}{c}2 \text { SLS } \\
(3)\end{array}$ & $\begin{array}{c}\text { 2SLS } \\
(4)\end{array}$ & $\begin{array}{c}\text { OLS } \\
(5)\end{array}$ & $\begin{array}{c}\text { OLS } \\
(6)\end{array}$ & $\begin{array}{l}\text { 2SLS } \\
(7)\end{array}$ & $\begin{array}{c}\text { 2SLS } \\
(8)\end{array}$ \\
\hline RSIndex $_{i t}$ & $\begin{array}{l}-0.040^{*} \\
(0.023)\end{array}$ & $\begin{array}{l}-0.035^{*} \\
(0.023)\end{array}$ & & & $\begin{array}{l}-0.340^{* * * *} \\
(0.088)\end{array}$ & $\begin{array}{l}-0.309^{*} \\
(0.085)\end{array}$ & & \\
\hline$H_{i t}$ & & & $\begin{array}{c}0.521^{* * *} \\
(0.177)\end{array}$ & $\begin{array}{c}0.371^{* * *} \\
(0.140)\end{array}$ & & & $\begin{array}{c}0.875^{* * *} \\
(0.246)\end{array}$ & $\begin{array}{c}0.652^{* * *} \\
(0.190)\end{array}$ \\
\hline Labor force concentration & & $\begin{array}{c}0.040^{* * *} \\
(0.009)\end{array}$ & & $\begin{array}{l}-0.026 \\
(0.002)\end{array}$ & & $\begin{array}{c}0.022^{*} \\
(0.014)\end{array}$ & & $\begin{array}{l}-0.024 \\
(0.003)\end{array}$ \\
\hline Unemployment rate & & $\begin{array}{l}-0.028 \\
(0.028)\end{array}$ & & $\begin{array}{l}-0.015^{*} \\
(0.009)\end{array}$ & & $\begin{array}{c}-0.022^{* * * *} \\
(0.075)\end{array}$ & & $\begin{array}{l}-0.021 * \\
(0.012)\end{array}$ \\
\hline Per capita personal income & & $\begin{array}{c}-2.162^{* * * *} \\
(0.884)\end{array}$ & & $\begin{array}{l}0.419^{* * *} \\
(0.059)\end{array}$ & & $\begin{array}{l}-0.463 \\
(2.238)\end{array}$ & & $\begin{array}{r}0.427^{* * *} \\
(0.087)\end{array}$ \\
\hline $\begin{array}{l}\text { Science and engineering degrees among higher } \\
\text { education degrees conferred }(\%)\end{array}$ & & $\begin{array}{c}0.004 \\
(0.013)\end{array}$ & & $\begin{array}{c}0.007 \\
(0.001)\end{array}$ & & $\begin{array}{c}0.024 \\
(0.038)\end{array}$ & & $\begin{array}{c}0.005 \\
(0.002)\end{array}$ \\
\hline Federal R\&D obligations per employed worker & & $\begin{array}{c}0.147^{* * *} \\
(0.061)\end{array}$ & & $\begin{array}{l}0.013^{* *} \\
(0.006)\end{array}$ & & $\begin{array}{l}0.579^{* * * *} \\
(0.173)\end{array}$ & & $\begin{array}{c}0.078 \\
(0.008)\end{array}$ \\
\hline $\begin{array}{l}\text { Year fixed effect } \\
\text { State fixed effect }\end{array}$ & $\begin{array}{l}\text { Yes } \\
\text { Yes }\end{array}$ & $\begin{array}{l}\text { Yes } \\
\text { Yes }\end{array}$ & Yes & Yes & $\begin{array}{l}\text { Yes } \\
\text { Yes }\end{array}$ & $\begin{array}{l}\text { Yes } \\
\text { Yes }\end{array}$ & Yes & Yes \\
\hline Observations & 543 & 543 & 645 & 645 & 560 & 560 & 662 & 662 \\
\hline Number of states & 51 & 51 & 51 & 51 & 51 & 51 & 51 & 51 \\
\hline R-squared & 0.9711 & 0.9736 & 0.0232 & 0.3833 & 0.7319 & 0.7464 & 0.6215 & 0.7635 \\
\hline
\end{tabular}

Note: This table reports the results (standard errors in parentheses) specified by Eq. (2) for all samples, where dependent variables are the state-size standardized patents and citations respectively. Models employed are pooled OLS with standard robustness errors (Models $1-2$ and Models $5-6$ ) and instrumented two-stage least squares (2SLS) (Models $3-4$ and Model $7-8)$. The instrument used is state median Tier 1 risk-based ratio. The existence of endogeneity $(H)$ is statistically significant in both 2SLS models at a $1 \%$ level for both Durbin Score Chi2 and Wu-Hausman tests. All estimations of RSIndex control for year and state fixed effects, while the models of $H$ only include year fixed effects because $H$ is derived from state-specific reduced-form revenue equation. Models $2,4,6$ and 8 include full set of control variables. ${ }^{* * *},{ }^{* *}$ and ${ }^{*}$ denote statistical significant levels of $1 \%, 5 \%$ and $10 \%$ respectively. 


\subsection{Robustness Tests}

Table 3 reports the results by employing various sampling approaches and by including additional controls for alternative financing sources. Robustness tests start by investigating, at a bigger regional level, how innovation benefits from improved banking market competition. Instead of state, we group the samples into 9 regions (New England, Mid-Atlantic, East North Central, West North Central, South Atlantic, East South Central, West South Central, Mountain and Pacific). This is important because such an approach allows the possibility of a firm to raise finance from neighbour states. Consistent results are found based on heteroskedasticaityrobust standard errors clustered by regions, where regional banking market competition (measured by $H$ ) improves regional innovation outputs (Models 2 and 10). Such effects are not statistically significant when using exogenous RSIndex (Models 1 and 9) and this is possibly because of the endogeneity issue and the reduced variation of deregulation measure in a bigger region where the standard deviation is 1.43 at state level and 1.03 at regional level.

The second robustness test controls for the outlier effects where observations from California and New York are excluded as they experienced a dramatic increase in both innovation activities and alternative financing sources, such as venture capital, during the period considered $^{5}$. Models 3, 4, 9 and 10 show that excluding these two states does not materially affect our key results. Additional tests include venture capital ratio as an additional control for time-variation in the availability of alternative financing sources. The ratio is defined as the fraction of total venture capital investments to total investment at state-level. Models 5, 6, 11 and 12 show consistent results with baseline models (Table 2) where banking market competition improves corporate innovation at state level ${ }^{6}$. Additional robustness tests ${ }^{7}$ are carried out by using alternative sampling approaches and baseline results are supported. 


\begin{tabular}{|c|c|c|c|c|c|c|}
\hline \multicolumn{7}{|c|}{ Panel A: $\ln (\text { Patent } / G D P)_{i t}$} \\
\hline & $\begin{array}{c}\text { OLS } \\
(1)\end{array}$ & $\begin{array}{c}\text { 2SLS } \\
\text { (2) }\end{array}$ & $\begin{array}{c}\text { OLS } \\
\text { (3) }\end{array}$ & $\begin{array}{l}\text { 2SLS } \\
\text { (4) }\end{array}$ & $\begin{array}{c}\text { OLS } \\
(5)\end{array}$ & $\begin{array}{c}\text { 2SLS } \\
(6)\end{array}$ \\
\hline RSIndex $x_{i t}$ & $\begin{array}{l}-0.115 \\
(0.085)\end{array}$ & & $\begin{array}{l}-0.034^{*} \\
(0.024)\end{array}$ & & $\begin{array}{l}-0.035^{*} \\
(0.023)\end{array}$ & \\
\hline$H_{i t}$ & & $\begin{array}{l}0.301^{*} \\
(0.177)\end{array}$ & & $\begin{array}{l}0.267^{* * *} \\
(0.125)\end{array}$ & & $\begin{array}{c}0.352^{* * *} \\
(0.138)\end{array}$ \\
\hline Venture Capital & & & & & $\begin{array}{c}0.186 \\
(0.494)\end{array}$ & $\begin{array}{c}0.579 \\
(0.420)\end{array}$ \\
\hline Control variables & Yes & Yes & Yes & Yes & Yes & Yes \\
\hline Year fixed effect & Yes & Yes & Yes & Yes & Yes & Yes \\
\hline State (Region) fixed effect & Yes & & Yes & & Yes & \\
\hline Observations & 99 & 117 & 521 & 619 & 543 & 645 \\
\hline Number of states (region) & 9 & 9 & 49 & 49 & 51 & 51 \\
\hline R-squared & 0.9955 & 0.9329 & 0.9722 & 0.4972 & 0.9736 & 0.4107 \\
\hline \multicolumn{7}{|c|}{ Panel B: $\ln (\text { Citation/GDP })_{i t}$} \\
\hline & $\begin{array}{c}\text { OLS } \\
(7)\end{array}$ & $\begin{array}{c}2 \text { 2SLS } \\
(8)\end{array}$ & $\begin{array}{c}\text { OLS } \\
(9)\end{array}$ & $\begin{array}{c}\text { 2SLS } \\
(10)\end{array}$ & $\begin{array}{r}\text { OLS } \\
(11)\end{array}$ & $\begin{array}{c}\text { 2SLS } \\
(12)\end{array}$ \\
\hline RSIndex $x_{i t}$ & $\begin{array}{l}-0.139 \\
(0.115)\end{array}$ & & $\begin{array}{c}-0.293^{* * *} \\
(0.084)\end{array}$ & & $\begin{array}{c}-0.309^{* * *} \\
(0.085)\end{array}$ & \\
\hline$H_{i t}$ & & $\begin{array}{l}0.362^{*} \\
(0.228)\end{array}$ & & $\begin{array}{c}0.566^{* * * *} \\
(0.171)\end{array}$ & & $\begin{array}{c}0.637^{* * *} \\
(0.188)\end{array}$ \\
\hline Venture Capital & & & & & $\begin{array}{c}0.948 \\
(0.963)\end{array}$ & $\begin{array}{c}0.452 \\
(0.393)\end{array}$ \\
\hline Control variables & Yes & Yes & Yes & Yes & Yes & Yes \\
\hline Year fixed effect & Yes & Yes & Yes & Yes & Yes & Yes \\
\hline State (Region) fixed effect & Yes & & Yes & & Yes & \\
\hline Observations & 98 & 116 & 538 & 636 & 560 & 662 \\
\hline Number of states (region) & 9 & 9 & 49 & 49 & 51 & 51 \\
\hline R-squared & 0.9961 & 0.9525 & 0.7432 & 0.8019 & 0.7465 & 0.7700 \\
\hline
\end{tabular}

Note: This table reports the results (standard errors in parentheses) for robustness tests by using alternative sampling approaches. All specifications include a full set of control variables. Models 1, 2, 9 and 10 consider samples of 9 regions; Models 3, 4, 9 and 10 test subsamples by excluding the observations from California and New York; Models 5, 6, 11 and 12 include venture capital ratio as an additional control variable. All RSIndex specifications employ pooled OLS standard robustness errors and include both year and state fixed effects. All $H$ specifications use instrumented two-stage least squares (2SLS) and include year fixed effects only. The instrument used is state median Tier 1 risk-based ratio. The existence of endogeneity $(H)$ is statistically significant in all 2SLS models at a $1 \%$ level for both Durbin Score Chi2 and Wu-Hausman tests. ${ }^{* * *},{ }^{* *}$ and ${ }^{*}$ denote statistical significant levels of $1 \%, 5 \%$ and $10 \%$ respectively.

The above empirical evidence could be dependent on the validity of indicators employed. To verify that the key results are not driven by the way that $H$ is derived, further robustness tests are carried out by using alternative competition measures, such as HerfindahlHirschman Index $\left(H H I_{i t}\right)$ and branch density ${ }^{8}\left(\right.$ Branch density $\left._{i t}\right)$. Results are reported in Table 4 where models (OLS) in Panel A follow the idea of exogenous banking market competition (e.g. Benfratello et al., 2008) and models (2SLS) in Panel B employ an instrumental variable approach to control for the endogeneity of banking market competition ${ }^{9}$. 
Consistent with baseline results, Table 4 shows clear evidence on the favourable effects of banking market competition (Branch density) and the unfavourable effects of concentration (HHI) on regional innovation outputs.

Additionally, an alternative proxy, 'innovator', is constructed to measure the extensive margin of innovations in a specific state. 'Innovator' is defined as the number of firms in a specific state, which file at least one patent per year (Hombert and Matray, 2017). Therefore, the greater the value of 'innovator', the more innovative a particular state is. With an exception of the insignificant OLS results (Panel A), Panel B Table 4 shows that the positive effects of banking market competition on various regional innovation measures are robust after controlling for endogeneity. Finally, due to the count-based nature of the variables, additional tests exploit a quasi-maximum likelihood (QML) Poisson models (Blundell and Powell, 2004) and the results, not reported but available on request, still hold. 


\begin{tabular}{|c|c|c|c|c|c|c|c|}
\hline \multirow{2}{*}{ Panel A: OLS Mode } & \multicolumn{2}{|c|}{ ln(Patent $/ G D P)_{i t}$} & \multicolumn{2}{|c|}{ ln $(\text { Citation/GDP })_{i t}$} & \multicolumn{3}{|c|}{ ln(Innovator $)_{i t}$} \\
\hline & & & & & & & \\
\hline & $(1)$ & $(2)$ & (3) & $(4)$ & $(5)$ & $(6)$ & $(7)$ \\
\hline RSIndex $x_{i t}$ & & & & & $\begin{array}{l}-0.102 \\
(0.071)\end{array}$ & & \\
\hline$H H I_{i t}$ & $\begin{array}{c}-0.217^{* * *} \\
(0.071)\end{array}$ & & $\begin{array}{c}-0.173^{* *} \\
(0.086)\end{array}$ & & & $\begin{array}{l}-0.079 \\
(0.271)\end{array}$ & \\
\hline Branch density $_{i t}$ & & $\begin{array}{c}0.110 \\
(0.088)\end{array}$ & & $\begin{array}{c}0.207 \\
(0.249)\end{array}$ & & & $\begin{array}{c}0.005 \\
(0.010)\end{array}$ \\
\hline Control variables & Yes & Yes & Yes & Yes & Yes & Yes & Yes \\
\hline $\begin{array}{l}\text { Year fixed effect } \\
\text { State fixed effect }\end{array}$ & Yes & Yes & Yes & Yes & $\begin{array}{l}\text { Yes } \\
\text { Yes }\end{array}$ & Yes & Yes \\
\hline Observations & 543 & 645 & 560 & 662 & 543 & 543 & 645 \\
\hline Number of states & 51 & 51 & 51 & 51 & 51 & 51 & 51 \\
\hline R-squared & 0.6925 & 0.9677 & 0.3048 & 0.7327 & 0.9641 & 0.9364 & 0.9640 \\
\hline \multicolumn{8}{|c|}{ Panel B: 2SLS Models } \\
\hline & $(8)$ & (9) & $(10)$ & $(11)$ & $(12)$ & (13) & (14) \\
\hline$H_{i t}$ & & & & & $\begin{array}{l}0.292^{* * *} \\
(0.092)\end{array}$ & & \\
\hline$H H I_{i t}$ & $\begin{array}{c}-0.421^{\text {*** }} \\
(0.122)\end{array}$ & & $\begin{array}{c}-0.683^{\text {**** }} \\
(0.149)\end{array}$ & & & $\begin{array}{c}-0.243^{\text {*** }} \\
(0.068)\end{array}$ & \\
\hline Branch density $_{i t}$ & & $\begin{array}{l}0.180^{* * *} \\
(0.064)\end{array}$ & & $\begin{array}{c}0.283^{* * * *} \\
(0.078)\end{array}$ & & & $\begin{array}{l}0.121^{* * * *} \\
(0.038)\end{array}$ \\
\hline Control variables & Yes & Yes & Yes & Yes & Yes & Yes & Yes \\
\hline Year fixed effect & Yes & Yes & Yes & Yes & Yes & Yes & Yes \\
\hline Observations & 543 & 645 & 560 & 662 & 645 & 543 & 645 \\
\hline Number of states & 51 & 51 & 51 & 51 & 51 & 51 & 51 \\
\hline R-squared & 0.6849 & 0.4753 & 0.2344 & 0.8378 & 0.7395 & 0.8620 & 0.7934 \\
\hline
\end{tabular}

Note: This table reports the results (standard errors in parentheses) for the robustness tests by using alternative measures of banking market competition and innovation. The dependent variables are the state-size standardized patents, citations and the number of innovators respectively. 'Innovator' is defined as the number of uniquely identified firms that file at least one patent in state $i$ in year $t$. Models employed in Panel A are pooled OLS with standard robustness errors (Models 1 - 7) and Panel B reports the results by using instrumented two-stage least squares (2SLS) (Models 8 - 14) where the instrument variable is state median Tier 1 risk-based ratio. The estimation of RSIndex includes both year and state fixed effects, while the models of $H$, HHI and Branch density include year fixed effects only. All specifications include a full set of control variables. ${ }^{* * *},{ }^{* *}$ and ${ }^{*}$ denote statistical significant levels of $1 \%, 5 \%$ and $10 \%$ respectively. 


\section{The heterogeneity of regional innovation}

\subsection{State $R \& D$ intensity}

Because of the costs and limited availability of credit supply caused by banking market imperfection, it is expected that the marginal economic contribution of an innovation output would be greater in those 'less innovative' regions than in those 'more innovative' regions ${ }^{10}$. A state is defined to have high $R \& D$ intensity $(R \& D$ intensity $=1)$ if its total $R \& D$ intramural expenditure to GDP ratio is greater than national average; low $\mathrm{R} \& \mathrm{D}$ intensity $(R \& D$ intensity $=0)$ otherwise. The model employed is as follows:

$$
\begin{array}{r}
\text { In(Innovation })_{i t}=\alpha+\beta_{1} \text { Competition }_{i t}+\beta_{2} R \& D \text { intensity }_{i t}+ \\
\beta_{3} \text { Competition }_{i t} \times R \& D \text { intensity }_{i t}+\gamma_{k} \sum X_{k, i t}+Y E A R_{t}+\varepsilon_{i t}
\end{array}
$$

where $\beta_{2}$ captures the effect of regional R\&D intensity on innovation outputs and $\beta_{3}$ measures its interactive effect with banking market competition on corporate innovation.

Panel A (Table 5) shows that both R\&D intensity and banking market competition ${ }^{11}$ improve regional innovation outputs in terms of both quantity and quality. The sign of the interaction term between $R \& D$ intensity and banking market competition is negative and in line with the expectation that innovation activities in states with lower R\&D intensity benefit more from improved banking market competition. Such an interaction effect is, however, statistically insignificant $(t=1.07)$ in the patent model. To further examine the validity of this mechanism, samples are categorized into $R \& D$ intensity low vs. high groups (results not reported but available on request) and the favourable effects of banking market competition on innovation are only statistically significant in those states with low R\&D intensity, supporting H2. 
Overall, above evidence ${ }^{12}$ suggests that credit supply is a limiting factor for regional innovation. Additional credit supply derived from improved banking market competition facilitates innovation in those regions where innovation are financially constrained and hence have low R\&D intensities.

Table 5 Heterogeneous Effects of Banking Market Competition

\begin{tabular}{|c|c|c|c|c|}
\hline & \multicolumn{4}{|c|}{ Model: 2SLS } \\
\hline & \multicolumn{2}{|c|}{ Panel A: R\&D Intensity } & \multicolumn{2}{|c|}{ Panel B: Patent Types Distribution } \\
\hline & $\begin{array}{l}\text { Patent } \\
\text { (1) }\end{array}$ & $\begin{array}{l}\text { Citation } \\
\text { (2) }\end{array}$ & $\begin{array}{c}\text { Patent } \\
\text { (3) }\end{array}$ & $\begin{array}{l}\text { Citation } \\
\text { (4) }\end{array}$ \\
\hline$H_{i t}$ & $\begin{array}{c}0.315^{*} \\
(0.211)\end{array}$ & $\begin{array}{l}0.827^{* *} \\
(0.372)\end{array}$ & $\begin{array}{c}0.613^{\text {**** }} \\
(0.237)\end{array}$ & $\begin{array}{c}0.848^{* * *} \\
(0.305)\end{array}$ \\
\hline$H_{i t} \times R \& D$ intensity $_{i t}$ & $\begin{array}{c}-0.178 \\
(0.167)\end{array}$ & $\begin{array}{l}-0.551^{*} \\
(0.300)\end{array}$ & & \\
\hline$R \& D$ intensity $_{i t}$ & $\begin{array}{c}0.263^{\text {**** }} \\
(0.110)\end{array}$ & $\begin{array}{c}0.507^{* * *} \\
(0.199)\end{array}$ & & \\
\hline$H_{i t} \times$ Patent distribution $_{i t}$ & & & $\begin{array}{c}-0.324^{* *} \\
(0.156)\end{array}$ & $\begin{array}{l}-0.273^{*} \\
(0.189)\end{array}$ \\
\hline Patent distribution $_{i t}$ & & & $\begin{array}{c}0.218^{*} \\
(0.114)\end{array}$ & $\begin{array}{c}0.166 \\
(0.139)\end{array}$ \\
\hline Control variable & Yes & Yes & Yes & Yes \\
\hline Year fixed effect & Yes & Yes & Yes & Yes \\
\hline Observations & 645 & 662 & 638 & 655 \\
\hline Number of states & 51 & 51 & 51 & 51 \\
\hline R-squared & 0.5780 & 0.7401 & 0.9336 & 0.6722 \\
\hline
\end{tabular}

Note: This table reports the results (standard errors in parentheses) of Eq. (5) where the dependent variables are the state-size standardized patents and citations. Panel A reports the regression estimates of Eq. (5). We define states having low $\mathrm{R} \& \mathrm{D}$ intensity $\left(R \& D\right.$ intensity $\left._{i t}=0\right)$ if its total $\mathrm{R} \& \mathrm{D}$ intramural expenditure to GDP ratio is below the country average in year $t$. Panel B reports the regression estimates of Eq. (6). We define the states to have a 'concentrated' (Patent distribution ${ }_{i t}=0$ ) patent distribution if the kurtosis of patent types distribution is greater than 3 in year $t$, to have a 'dispersed' patent distribution otherwise. Models employed across all specifications are the instrumented two-stage least squares (2SLS) with the instrument variable 'state median Tier 1 risk-based ratio'. The existence of endogeneity $(H)$ is statistically significant in all 2SLS models at a $1 \%$ level for both Durbin Score Chi2 and Wu-Hausman tests. All specifications include a full set of control variables and year fixed effects. ${ }^{* * *},{ }^{* *}$ and ${ }^{*}$ denotes statistical significant level of $1 \%, 5 \%$ and $10 \%$ respectively.

\subsection{Type distribution of innovation outputs}

Results so far have supported market power hypothesis that regional corporate innovation activities benefit from banking market competition which expands the availability of credit within a state and lowers the cost of external finance. This section investigates how the information effect alters the marginal impact of banking competition on regional innovation as shown by Eq. (6) 
$\ln \left(\right.$ Innovation $_{i t}=\alpha+\beta_{1}$ Competition $_{i t}+\beta_{2}$ Patent distribution $_{i t}+$ $\beta_{3}$ Competition $_{i t} \times$ Patent distribution $+\gamma_{k} \sum X_{k, i t}+Y E A R_{t}+\varepsilon_{i t}$

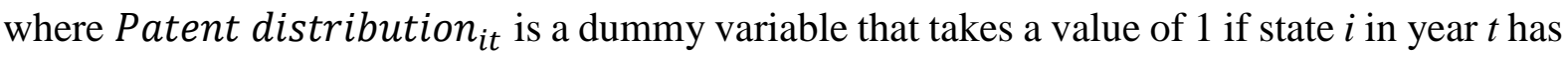
'dispersed' patents and 0 if the states has 'concentrated' patents. The interaction term, Competition $_{i t} \times$ Patent distribution $_{i t}$, captures the heterogeneous effects of banking market competition on the nature of regional innovation activities, in terms of either concentrated or dispersed patent types. Patents are grouped into 6 types (chemical (excluding drugs), computers and communications, drugs and medical, electrical and electronics, mechanical and other) and state ${ }_{i t}$ is defined to have a 'concentrated' ('dispersed') patent type distribution when the kurtosis of patent types is greater (lower) than 3 .

The results of Eq. (6) are reported in Panel B (Model 3 and 4) in Table 5, showing that banking market competition has a stronger favourable effect on innovation outputs in those states where patents are concentratedly distributed (greater kurtosis). For instance, based on the coefficient estimate reported in Model 3, the marginal effect of $H$ on the number of patents is $0.613(t=2.59)$ if a state has concentrated patent types (kurtosis $>3$ ). While in a state in which patent distribution is dispersed (kurtosis < 3), the marginal effect of $H$ on innovation output would be $47.15 \%$ lower. Such evidence supports $\mathbf{H 3}$ and suggests that with improved banking market competition and credit supply, banks would channel their funds to finance a certain types of innovation because of the economies of scale occurred in collecting relevant information from borrowers. By doing so, banks alleviate the problem of asymmetric information embedded within corporate innovation activities and they are reluctant to further diversify risk by financing a variety types of innovation activities. On the other hand, regions with more concentrated innovation activities benefit more from improved banking market competition, supporting the "specialization" argument that regions would profit by developing distinctive areas of specialization and strategically concentrating policy efforts on those 
specialization domains (Muller et al., 2017). This result is also supported by using a grouping (dispersed vs. concentrated patent distribution) approach (results not reported but available on request).

\section{Conclusion}

In the last decade, there has been an increasing attention paid to the effects of banking market deregulation and development on corporate innovation, for example in U.S. (Amore et al., 2013), Italy (Benfratello et al., 2008) and internationally (Hsu et al., 2014), mainly focusing on firm level evidence. In contrast, this study uses NBER patent database, which has about 97\% of the patents filed correspond to product patents (Chava et al., 2013), to investigate how regional corporate innovation benefits from improved banking market competition. It is a departure from prior research on firm level innovation (e.g. Amore et al., 2013), and makes unique contributions to regional innovation research by focusing on state level for three particularly important reasons. Firstly, because of the variation of such effects over firm level characteristics, an investigation at regional (e.g. state) level helps us capture the aggregate effects of banking market competition on regional innovation. Secondly, a regional study at state level may help policy-makers to set up more 'tailored' policies to facilitate corporate innovation activities (Hsu et al., 2014). Thirdly, prior research has considered generic regional factors (e.g. employment), in innovation studies and neglected the moderating effects of regional innovation patterns, such as R\&D intensity and type distribution of innovation outputs, when investigating the determinations of innovation. This study fills in such gaps and shows that local banking market competition improves regional innovation outputs, in terms of increased numbers of both patents obtained and citations they receive, and such favourable 
effects are robust to various measures and empirical approaches, supporting the market power hypothesis.

This research also investigates the possible mechanisms and contributes to regional innovation literature by offering new evidence on how regional innovation activities react to banking market competition in different ways. We show that in U.S., the favourable effects from banking market competition are stronger in those states with lower R\&D intensity where additional innovation makes a greater marginal economic contribution. We also document the important roles played by information in financing innovation, where states with more concentrated patent types benefit more from the improved banking market competition. It suggests that due to the uncertain nature and information opaqueness of innovation activities, information plays a more important role in bank lending decision makings than risk diversification, where banks could alleviate asymmetric information problems by collecting more specialized information.

This study also provides three relevant implications for practice. Firstly, consistent with Fabrizio and Thomas (2012) who study the impacts of local demand on innovation, this research underscores the strategic importance of location decisions and demonstrates that location choices should consider the access to finance for innovation investment. Our results emphasize that regional banking market competition plays an important role in facilitating corporate innovation and this would be especially important for smaller innovative firms who rely more heavily on local banks than large and public firms who have a better access to distant banking markets and equity markets. Secondly, the results reported above on specialized information encourage managers to enhance information quality of those informationally opaque innovation projects so as to have a better access to finance from banking markets. This is especially important when banking market becomes more competitive and banks have weaker incentives to invest in private information acquisition because of the possible free-rider 
problem in competitive banking markets (Han et al., 2009). Finally, since banking market deregulation in U.S. in 1990s, state governments have become more open to both inter and intra state banking and local banking markets have become more competitive. Those states with low R\&D intensity and more concentrated innovation outputs could develop regional innovativeness by further improving local banking market competition.

We recognize that this research is subject to some limitations. The empirical data on patent information publicly available from NBER are only until 2004, limiting the potential of relevant research to further investigate the effects of bank market development and financial crisis. Despite the comprehensive nature of our data on patents and citations, we would have liked to investigate the effects of banking market competition on other types of innovation activities, such as process innovation and those without patents. Unfortunately, these data remain unavailable from the databases. Although banks and other depository financial institutions remain the pre-eminent supplier to business (Mach and Wolken, 2006), sources of funding from non-bank have become more readily available which have led to changes (Kirby and Worner, 2014) which our data do not fully allow us to capture. Hence, we call for future research on how the mix of bank and non-bank financing impacts on regional corporate innovation in U.S and many other countries.

Although we use patent data from both public and private firms, our results, like those studies on firm level innovation (e.g. Chava et al., 2013), may still under-present the innovation activities undertaken by young and very small firms whose information is not publicly available. Nonetheless, we hope this research encourages other researchers to investigate further nuances in the relationship between corporate innovation and banking market structure. Future studies, for example, could extend our research by considering the heterogeneity of banking market competition effects on process and product innovation. Finally, future research could also 
consider the possible non-monotonical effects of banking competition so as to theorize and identify the boundary conditions of banking market power.

\section{References}

Amit R, Glosten L and Muller E (1990) Entrepreneurial ability, venture investments, and risk sharing. Management Science 36(10): 1232-1245.

Amore MD, Schneiderb C and Žaldokas A (2013) Credit supply and corporate innovation. Journal of Financial Economics 109(3): 835-855.

Archibugi D (1992) Patenting as an indicator of technological innovation: A review. Science and Public Policy 19(6): 357-368.

Benfratello L, Schiantarelli F and Sembenelli A (2008) Banks and innovation: Microeconometric evidence on Italian firms. Journal of Financial Economics 90(2): 197217.

Berger AN, Miller NH, Petersen MA, Rajan RG and Stein JC (2005) Does function follow organizational form? Evidence from the lending practices of large and small banks. Journal of Financial Economics 76(2): 237-269.

Bikker JA and Haaf K (2002) Competition, concentration and their relationship: An empirical analysis of the banking industry. Journal of Banking and Finance 26(11): 2191-2214.

Black SE and Strahan PE (2002) Entrepreneurship and bank credit availability. Journal of Finance 57(6): 2807-2833.

Blundell RW and Powell JL (2004) Endogeneity in semiparametric binary response models. Review of Economic Studies 71: 655-679.

Boot AW and Thakor AV (2000) Can relationship banking survive competition? Journal of Finance 55(2): 679-713. 
Breznitz SM, O'Shea RP and Allen TJ (2008) University commercialization strategies in the development of regional bioclusters. Journal of Product Innovation Management 25(2): $129-142$.

Capello R and Lenzi C (2014) Spatial heterogeneity in knowledge, innovation, and economic growth nexus: Conceptual reflections and empirical evidence. Journal of Regional Science 54(2): 186-214.

Casson PD, Martin R and Nisar TM (2008) The financing decisions of innovative firms. Research in International Business and Finance 22(2): 208-221.

Chava S, Oettl A, Subramanian A and Subramanian KV (2013) Banking deregulation and innovation. Journal of Financial Economics 109(3): 759-774.

Claessens S and Laeven L (2004) What drives bank competition? Some international evidence. Journal of Money, Credit and Banking 36(3): 563-583.

Cornaggia J, Mao Y, Tian X and Wolfe B (2015) Does banking competition affect innovation? Journal of Financial Economics 115(1): 189-209.

Czarnitzki D and Hottenrott H (2011) R\&D investment and financing constraints of small and medium-sized firms. Small Business Economics 36(1): 65-83.

Degryse H and Ongena S (2005) Distance, lending relationships, and competition. Journal of Finance 60(1): 231-266.

Dosi G (1982) Technological paradigms and technological trajectories. Research Policy 11(3): $147-162$.

Fabrizio KR and Thomas LG (2012) The impact of local demand on innovation in a global industry. Strategic Management Journal 33(1): 42-64.

Faria AP and Barbosa N (2014) Does venture capital really foster innovation. Economics Letters 122(2): 129-131. 
Francis B, Hasan I, Huang Y and Sharma Z (2012) Do banks value innovation? Evidence from US firms. Financial Management 41(1): 159-185.

Furman JL, Porter ME and Stern S (2002) The determinants of national innovative capacity. Research Policy 31(6): 899-933.

Gawalt JR (2008) Science and engineering indicators. Arlington, VA: National Science Board. Hall BH, Jaffe AB and Trajtenberg M (2001) The NBER patent citation data file: Lessons, insights and methodological tools. Working Paper No. 8498, Cambridge, MA: National Bureau of Economic Research.

Hall BH, Jaffe A and Trajtenberg M (2005) Market value and patent citations. RAND Journal of Economics 36(1): 16-38.

Han L, Fraser S and Storey DJ (2009) Are good or bad borrowers discouraged from applying for loans? Evidence from U.S. small business credit markets. Journal of Banking and Finance 33(2): 415-424.

Hombert J and Matray A (2017) The real effects of lending relationships on innovative firms and inventor mobility. Review of Financial Studies 30(7): 2413-2445.

Hong J, Feng B, Wu Y and Wang L (2016) Do government grants promote innovation efficiency in China's high-tech industries?. Technovation 57: 4-13.

Hsu PH, Tian X and Xu Y (2014) Financial development and innovation: Cross-country evidence. Journal of Financial Economics 112(1): 116-135.

Kirby E and Worner S (2014) Crowd-funding: An infant industry growing fast. Working Paper No. SWP3/2014. Madrid: IOSCO.

Melançon Y and Doloreux D (2013) Developing a knowledge infrastructure to foster regional innovation in the periphery: A study from Quebec's coastal region in Canada. Regional Studies 47(9): 1555-1572. 
Mach TL and Wolken JD (2006) Financial services used by small businesses: evidence from the 2003 survey of small business finances. Federal Reserve Bulletin (Oct.): 167-195.

Mishra S, Kim D and Lee DH (1996) Factors affecting new product success: Cross-country comparison. Journal of Product Innovation Management 13(6): 530-550.

Morgan K (2016) Nurturing novelty: Regional innovation policy in the age of smart specialisation. Environment and Planning C: Politics and Space 35(4): 569-583.

Muller E, Zenker A, Hufnagl M, Héraud J and Schnabl E (2017) Smart specialisation strategies and cross-border integration of regional innovation systems: Policy dynamics and challenges for the Upper Rhine. Environment and Planning C: Politics and Space 35(4): $684-702$.

Pavitt K (2001) Managing global innovation: Uncovering the secrets of future competitiveness. Research Policy 30(1): 176-177.

Popov A and Roosenboom P (2012) Venture capital and patented innovation: Evidence from Europe. Economic Policy 27(71): 447-482.

Redmond WH (1994) Diffusion at sub-national levels: A regional analysis of new product growth. Journal of Product Innovation Management 11(3): 201-212.

Rice T and Strahan PE (2010) Does credit competition affect small-firm finance? Journal of Finance 65(3): 861-889.

Rosenzweig S and Mazursky D (2014) Constraints of internally and externally derived knowledge and the innovativeness of technological output: The case of the United States. Journal of Product Innovation Management 31(2): 231-246.

Savignac F (2008) Impact of financial constraints on innovation: What can be learned from a direct measure? Economics of Innovation and New Technology 17(6): 553-569.

Strahan PE (2003) The real effects of U.S. banking deregulation. Working Paper No. 02-39, Philadelphia, PA: Wharton School Center for Financial Institutions. 
Uyarra E, Flanagan K, Magro E and Zabala-Iturriagagoitia JM (2017) Anchoring the innovation impacts of public procurement to place: The role of conversations. Environment and Planning C: Politics and Space 35(5): 828-848.

Wonglimpiyarat $\mathbf{J}$ (2013) The role of equity financing to support entrepreneurship in Asia The experience of Singapore and Thailand. Technovation 33(4-5): 163-171. 


\section{Appendix: Key Variable Definitions}

\section{Innovation variables:}

$\ln (\text { Patent } / G D P)_{i t}$ : Natural logarithmic state GDP standardized number of patents generated in state $i$ year $t$, where the aggregated counts are adjusted by averaging the number of patents within three years (year $t$ to $t+2$ ).

$\ln (\text { Citation } / G D P)_{i t}$ : Natural logarithmic state GDP standardized number of citations of patents received in state $i$ year $t$, where the number of citations are adjusted for truncation and averaging within three years (year $t$ to $t+2$ ).

$\ln (\text { Innovator })_{i t}$ : Natural logarithmic values of the number of firms that file at least one patent in state $i$ year $t$. 'Firms' are clustered according to unique (original) and time-invariant identifier assignee identifier provided by USPTO in NBER patent dataset.

$\ln (\text { Patent } / R \& D)_{i t}$ : Natural logarithmic ratio of the adjusted count of patents to total R\&D expenditures in state $i$ year $t$.

$\ln (\text { Citation/Patent })_{i t}$ : Natural logarithmic ratio of the adjusted number of citations to the number of patents in state $i$ year $t$.

\section{Banking market competition variables:}

RSIndex $_{i t}$ : Rice and Strahan (2010) index, a categorical measure of banking deregulation based on the variation of state openness to interstate branching in state $i$ year $t$, ranging from 0 (deregulated) to 4 (highly regulated).

$H_{i t}$ : Panzar-Rosse (1984) H-statistic, the sum of the elasticity of total revenue with respect to three inputs prices used by banks, which are the labor, funds and physical capital, ranging from 0 to 1 . 
$H H I_{i t}$ : Herfindahl-Hirschman Index, the sum of squared share of deposits for each branch in state $i$ year $t$. It is weighted averages across markets for banking institutions in multiple local markets using the proportions of total deposits as the weights.

Branch density ${ }_{i t}$ : The number of branches per $\mathrm{km}^{2}$ in state $i$ year $t$.

\section{Other control variables:}

Labor force concentration $_{i t}$ : The proportion (\%) of employment in population in state $i$ year $t$.

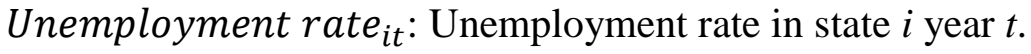

$\ln (\text { Income })_{i t}$ : Natural logarithmic value of per capita personal income in state $i$ year $t$.

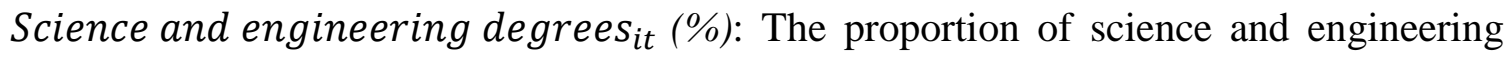
degrees by higher education degrees in state $i$ year $t$, including bachelor's, master's, and doctorate degrees covering physical, computer, agricultural, biological, earth, atmospheric, ocean, and social sciences, psychology, mathematics, and engineering.

$\ln (\text { Federal } R \& D \text { obligations })_{i t}$ : Natural logarithm of federal $\mathrm{R} \& \mathrm{D}$ spending per employee in science and engineering occupations in state $i$ year $t$.

Venture capital $_{i t}$ : Ratio of total venture capital investments to total investment in state $i$ year $t$.

$R \& D$ intensity $_{i t}$ : A dummy variable coded as 1 if state $\mathrm{i}_{\mathrm{i}}$ in year $\mathrm{r}_{\mathrm{t}}$ has a higher than country average ratio of total $R \& D$ intramural expenditure to GDP (i.e. high intensity), and 0 otherwise (i.e. low intensity).

Patent distribution $_{i t}$ : A dummy variable coded as 1 if state $i$ in year $t$ has 'concentrated' patent types (kurtosis $>3$ ) and 0 if the states has 'dispersed' patent types (kurtosis $<3$ ). 
${ }^{1}$ This is because some accounting terms are not standardized and it is possible that financial constraints at firm
level influence the decision whether to expense or to capitalize R\&D. The main drawback of patent-metrics is that not all firms patent their innovations and not all patent applications are successful (Archibugi, 1992; Hombert and Matray, 2017).

${ }^{2}$ The derivation of $H$ is available from the authors upon request.

${ }^{3}$ A detailed discussion on the reasons, test of endogeneity and instrumental variables is available from the authors upon request. Our following results are still robust to an alternative instrument used, tangible capital ratio, and the results are not reported but available from the authors upon request.

${ }^{4}$ Both Durbin Score Chi2 $(p<0.01)$ and Wu-Hausman F $(p<0.01)$ tests suggest the existence of endogeneity of $H$. The effect of instrumental variable, Tier 1 ratio, on $H$ is negative (coefficient $=-0.023)$ and significant at $1 \%(p$ $<0.01$ ) level. $F$-statistic of Eq. (3) is 32.60 with a $p$-value of 0.000 . The results are not reported but available from the authors on request.

${ }^{5}$ For example, in 1996, the annual growth rate of patents applied from California was $25.2 \%$ and $19.4 \%$ in New York; California received nearly half of total venture capital investment in U.S and New York also remained top5 states receiving venture capital that accounted for $3.6 \%$ of the total investment in U.S. (Gawalt, 2008).

${ }^{6}$ The impacts of venture capital on corporate innovation are positive but statistically insignificant in all specifications. For example, in Model 6, the coefficient estimate of venture capital is $0.579(t=1.38)$. The evidence partially supports existing literature on the contributions made by venture capital to foster innovation (e.g. Faria and Barbosa, 2014) while the insignificant results could be explained by the potential endogeneity of venture capital (e.g. Popov and Roosenboom, 2012) that we could not control for in our analysis due to the limited information available.

${ }^{7}$ Results are available from the authors upon request.

${ }^{8}$ Geographical proximity allows banks to be more effective in collecting soft information from borrowers and to reduce screening and monitoring costs, particularly for small firms. A decrease in such costs has beneficial effects on the cost of and access to finance. Therefore, it is reasonable to expect that higher branch density would have a positive effect on credit supply and reduce the probability of being financially constrained for businesses (Degryse and Ongena, 2005).

${ }^{9}$ The instrument 'Tier 1 capital ratio' used for H-statistic is also appropriate for both HHI and branch density. The correlations of state median Tier 1 risk-based capital ratio with HHI and Branch density are 0.4973 and -0.2707 , respectively. The two correlation coefficients are both significantly different from zero at $1 \%$ level.

${ }^{10}$ To test this hypothesis, GDP is regressed on innovation (patents and citations) and other controls (e.g. coincident index). The marginal contribution to local GDP of regional (natural log transformed) innovation in states with low $R \& D$ intensity is 1.5 times as high as that in states with high R\&D intensity. Therefore, an innovation makes a greater contribution to local GDP when local R\&D intensity is low. Results are not reported but available from the authors upon request.

${ }^{11}$ In view of the main purpose of this research and the advantages of $H$-statistic in measuring competition degree, henceforth, it provides comments only on the 2SLS estimates of H-statistic. However, the estimates of RSIndex are qualitatively identical and available from the authors on request.

${ }^{12} \mathrm{~A}$ potential bias could be that the results are driven by a few sample firms which rely heavily on bank market and innovate extensively. This is because there could be a large number of firms generating patents but not necessarily receiving either bank loans or venture capital investment. We thank an anonymous referee for raising this point. To explicitly address this issue, we control for firm level information transparency, the degree of reliance on external finance and the availability of collateral and our results, not reported by available from the authors on request, still hold. 